\title{
Intricacies and inter-relationships between HIV disclosure and HAART: a qualitative study
}

R. L. Kitzzman, ${ }^{1}$ S. B. Kirshenbaum, ${ }^{1}$ B. Dodge, ${ }^{1}$ R. H. Remien, ${ }^{1}$ A. A. Ehrhardt, ${ }^{1}$ M. O. Johnson, ${ }^{2}$ L. E. Kittel, ${ }^{1}$ S. Daya, ${ }^{1}$ S. F. Morin, ${ }^{2}$ J. Kelly, ${ }^{3}$ M. Lightfoot, ${ }^{4}$ M. J. Rotheram-Borus ${ }^{4} \&$ THE NIMH Healthy Living TRIAL GROUP

${ }^{1}$ HIV Center for Clinical and Behavioral Studies, New York State Psychiatric Institute and Columbia University, New York $\mathcal{F}^{2}$ Center for AIDS Prevention Studies, University of California, San Francisco, ${ }^{3}$ Center for AIDS Intervention Research, Medical College of Wisconsin, Milwaukee $\mathcal{E}^{4}$ Center for Community Health, UCLA Neuropsychiatric Institute Los Angeles, California, USA

\begin{abstract}
This study aimed to understand whether and how highly active antiretroviral treatment (HAART) affects views and patterns of disclosure and how disclosure interacts with treatment decisions. One hundred and fifty-two HIV-positive adults (52 MSM, 56 women and 44 IDU men) from four US cities participated in two to three-hour, semi-structured interviews in 1998-99. Results indicate that HAART interacts with and shapes HIV disclosure issues in several ways. Medications may 'out' people living with HIV. Thus, in different settings (e.g. work, prisons, drug rehabs and public situations), some try to hide medications or modify dosing schedules, which can contribute to non-adherence, and affect sexual behaviours. Disclosure of HIV and/or HAART may also result in antagonism from others who hold negative attitudes and beliefs about HAART, potentially impeding adherence. Observable side effects of medications can also 'out' individuals. Conversely, medications may improve appearance, delaying or impeding disclosure. Some wait until they are on HAART and look 'well' before disclosing; some who look healthy as a result of medication deny being HIV-positive. Alternatively, HIV disclosure can lead to support that facilitates initiation of, and adherence to, treatment. HIV disclosure and adherence can shape one another in critical ways. Yet these interactions have been under-studied and need to be further examined. Interventions and studies concerning each of these domains have generally been separate, but need to be integrated, and the importance of relationships between these two areas needs to be recognized.
\end{abstract}

Address for correspondence: Robert L. Klitzman, MD, HIV Center for Clinical and Behavioral Studies, Columbia University/New York State Psychiatric Institute, 1051 Riverside Drive, New York, NY 10032, USA. Tel: +1 212740 7324; Fax: +1 212740 3508; E-mail: rlk2@columbia.edu 


\section{Introduction}

Disclosure of HIV serostatus continues to pose fundamental problems for people living with HIV (PLWH), but have shifted due to the advent of new medications, in ways that have not been fully explored. Researchers have highlighted numerous issues associated with HIV disclosure to partners, family, colleagues and health care providers (Klitzman \& Bayer, 2003; Sepkowitz, 2001), yet the relationships between decisions about disclosing and about starting and adhering to highly active antiretroviral treatment (HAART) have been under-studied. Does disclosure always facilitate adherence? Does adherence facilitate disclosure? Many advocates have hoped that improved treatment would lessen the stigma associated with HIV and ease the lives of PLWH. But do individuals who are or are not 'out' about their HIV status confront different issues when taking medications?

Issues of HIV disclosure and adherence to HAART have been examined separately within the literature. The decision to disclose is complex and may potentially involve significant anxiety, stigma and shame, leading to isolation or even threats to personal safety (Klitzman, 1999; Klitzman \& Bayer, 2003; Stein et al., 1998). Consequently, a significant number of PLWH do not disclose to sexual partners (Perry et al., 1990; Stempel et al., 1995).

The relationship between HIV disclosure and sexual risk behaviour is complex. Disclosure may be associated with reduced sexual risk behaviour (Kalichman \& Nachimson, 1999) and having fewer sexual partners (Marks et al., 1991). Perceived partner serostatus may influence these patterns. Unprotected sex may be more likely in seroconcordant couples who have disclosed (Marks et al., 1994). In another study, 40\% of PLWH did not inform all sexual partners of their status, but were more likely than disclosers to use condoms regularly (Marks \& Crepaz, 2001). Individuals may feel that safer sex obviates the need for disclosure.

Many infected individuals do not inform parents and siblings due to complex personal, health and family concerns, including the emotional needs of children, family finances and associated stressors (DeMatteo et al., 2002). Approximately $90 \%$ of women revealed their HIV status to their lovers, although only half or less did so with family (Simoni et al., 1995). In another study, 57\% disclosed to their children (Kirshenbaum, 1999; Kirshenbaum \& Nevid, 2002). In general, disclosure occurs due to a sense of moral responsibility, needs for support or, with partners, concerns for the latter's health. Non-disclosure results from fears of rejection, feelings of dependence or shame, and desires to maintain secrecy and/or protect others from emotional distress (Klitzman \& Bayer, 2003; Simoni et al., 1995). Disclosure may have a variety of negative consequences such as rejection or even violence (Gielen et al., 2000a,b).

Individuals may disclose to family and friends when becoming ill and no longer being able to keep their health status a secret (Babcock, 1998; Kalichman, 1995; Mansergh et al., 1995). But disease progression is not necessarily related to disclosure to sexual partners (Mansergh et al., 1995; Perry et al., 1994; Serovich, 2001). With the increased availability and effectiveness of HAART, the relationship between disease progression and disclosure may be less clear. PLWH may selectively disclose if the anticipated rewards outweigh the perceived costs (Derlega et al., 1993), but it remains unclear how individuals determine such costs and rewards, and vary in such assessments (Klitzman \& Bayer, 2003).

Adherence to HAART is medically important for treatment success (Chesney et al., 2000; Crespo-Fierro, 1997; Kastrissios et al., 1998; Molaghan, 1997; Paterson et al., 2000; Rodriguez Rosado et al., 1998) to avoid viral resistance (Paterson et al., 2000; Wahl \& Nowak, 2000) and to increase survival (Garcia de Olalla et al., 2002). Improved and simpler dosing schedules do not alleviate the need for regular dosing or concerns about viral resistance. 
Overall, four groups of factors have been associated with adherence: (1) patient factors; (2) medication characteristics; (3) interpersonal characteristics (e.g. social supports); and (4) the general health care system (Chesney et al., 2000; Remien, 1998). Yet a deficit of scientific information exists on how disclosure issues relate to these domains. Disclosure may help or hinder social support.

Although research on HIV disclosure after the advent of HAART is abundant, few, if any studies, have examined disclosure as it directly relates to HAART-associated issues. While some studies of disclosure include CD4 count and other medical indicators as variables of interest, the role of HAART and adherence have received little attention in the disclosure literature. In one of the only studies, Mellins et al. (2002) found disclosure of maternal HIV status to children to be related not to adherence to HAART, but to ability to adhere to medical appointments. As a reason for missing doses, not wanting others to see one taking medication is often reported (Chesney et al., 2000; Gifford et al., 2000). Similarly, HIV-associated stigma can impede treatment seeking and medication acceptance and adherence (Chesney \& Smith, 1999). Side effects can reduce quality of life (Johnson et al., 2003b) and are associated with non-adherence (Ammassari et al., 2001; Johnson et al., 2002; Remien et al., 2003; Johnson et al., 2003a). For example, lipodystrophy may be associated with both feelings of being recognizable as HIV-positive (Oette et al., 2002) and failure to adhere to HAART (Duran et al., 2001).

Thus, critical questions remain. Does HAART affect views and patterns of disclosure among PLWH, and if so, how? In what ways does disclosure interact with decisions to start or continue treatment?

\section{Methods}

\section{Study context}

We conducted in-depth interviews with HIV-positive men and women in Los Angeles, Milwaukee, New York and San Francisco between 1998 and 1999 as the initial formative phase of an intervention trial which entered the field in the spring of 2000, and was designed to improve coping skills, reduce transmission risk behaviours and improve medical adherence and other health care behaviours. Interviews covered a wide range of areas enabling us to increase our understanding of issues faced by HIV-positive individuals post-HAART. Interview data were used to inform the tailoring of the intervention to our study subpopulations, and train staff regarding the issues most relevant to participants.

\section{Participants and eligibility}

A total of 152 in-depth interviews were conducted with HIV-positive adults, including 52 men who have sex with men, 56 women and 44 male injection drug users. Individuals were eligible to participate if they were HIV-positive, at least 18 years old, able to complete the interview in English and able to give informed consent. Sixty interviews (20/sub-group) were conducted in New York (the lead site in this phase of the trial) and approximately 30 interviews (ten/ subgroup) in each of the other sites.

\section{Procedures}

Participants were recruited from HIV primary care clinics and community-based organizations via provider referrals, word-of-mouth or study announcements at recruitment sites or in 
newsletters. Those interested contacted study staff, via telephone or in person, on site. Staff described study objectives and procedures to potential participants and obtained consent for enrollees. Experienced interviewers with master's level social science education received centralized comprehensive training with ongoing supervision. Interviews lasting two to three hours followed a structured schedule of open-ended questions with follow-up probes as needed. Participants provided informed consent, and were paid $\$ 25$ for completing the interview. All interviews were audiotaped and transcribed.

\section{Assessment interview}

Interviews were broad based and designed to elicit the meanings, norms, interpersonal contexts, daily routines and other defining features of participants' lives in their own terms and words (Patton, 1990; Strauss \& Corbin, 1990) that could be expected significantly to affect health, sexual and drug use behaviours, psychological and practical adaptation to HIV, and preferences for and participation in a behavioural intervention. Integral to these interviews were sections on HIV disclosure and HAART. All participants were asked the following: How do you think the people in your life think about you taking/starting/stopping the medications? What gets in the way of taking the medication? What helps you be able to take the medication the way the doctor prescribed? Did you tell your physician that you stopped taking the medication? Do you tell your sexual partners that you have HIV or do you keep it to yourself? Why/Why not? Participants were asked how the following targets have reacted to their having HIV: family; doctors, nurses and other health care providers (outside of HIV clinics or agencies) friends; people in the neighbourhood; landlords, coworkers and employers. Interviewers were instructed to probe independently as necessary, to ascertain more fully the respondent's awareness, knowledge, attitudes and actual experiences concerning these issues.

\section{Analysis of qualitative data}

Analyses were informed by grounded theory (Strauss \& Corbin, 1990) and were conducted in two phases. In the first phase, investigators reviewed transcripts to identify primary coding categories across the broad range of topics covered, as well as a range of sub-codes and themes present within each topic area. Identified coding categories and themes were organized into a formal codebook. A coding team of eight evaluated four transcripts (one from each city, across sub-populations) as a group to establish coding consensus and refine coding schema. New themes that did not fit into this original coding framework were discussed, and modifications were made when deemed appropriate. We refined, merged or sub-divided thematic categories, when suggested by associations, overlap or diversions in the data. Inter-rater discrepancies were discussed until obtaining a consensus. This process was repeated until all raters achieved concordance on almost all decisions, after which pairs of evaluators from the larger team coded additional interviews $(n=38)$ until reaching a clear saturation for major and minor themes and codes.

Based on our analyses of this data set as a whole, several themes emerged concerning the complex relationships between disclosure and HAART. Hence, the second phase of analyses examined data from all 152 interviews and focused on the variables we found to be most salient and relevant to these relationships. At the same time, we explored these issues within the broader context of participants' lives. We organized and identified themes into formal coding grids and extracted illustrative quotes relevant to these themes from the original transcripts. At least two members of the data analytic team conducted analyses to ensure 
coding reliability. Findings report on the patterns of relationships between variables found to be most significant. Our analyses did not indicate the clear presence of other variables that would significantly alter an understanding of the pattern of relationships described here. The themes found and described here also appeared to have face validity.

\section{Results}

\section{Sample description}

Table 1 presents demographic and background data for the sample $(N=152)$. The majority of individuals in each sub-group ranged in age from late thirties to early forties, and currently took HIV medication therapy.

Several key themes emerged in the data, including relationships between disclosure and HAART (see Figure 1).

\section{Taking HAART as precipitating HIV disclosure}

Taking medications may 'out' infected individuals. Such concerns arise in different settingsparticularly at work and in other public environments. Even within the confines of one's own home, one's status could be inadvertently disclosed to others. As one gay man said, 'Some friends came over to my house and opened the medicine cabinet. They got a shock, "Oh my God, what is all this?"' (NY MSM). As a result, many try to hide medications, and/or adopt dosing schedules and routines to conceal their pill taking as well as their diagnosis from others, which can cause additional stress:

Sometimes I may be out somewhere and I have to take my pills. So I would want to sneak off into this quiet little corner and take my pills or go in the bathroom. You want to be sure you don't leave them in your medicine chest at home. You're always feeling like you're trying to cover up something, and that could be an emotional hassle, a mental strain on yourself, too (LA MSM).

Some attempt to disguise the nature of their medication:

I usually hide it. I rip all the insignias off the bottle so if anybody did see the bottle, they wouldn't know even what the pills are. Because I don't want anybody to know (LA MSM).

Others were more comfortable taking medication at work or in public, but reported lying about their reasons for having to take pills:

Especially when I was working, I had to stop when I had to take some medication. People are like, 'What are you taking?' You just come up with some off-the-wall excuse. ...Just, oh, you know, it's the only thing that keeps my nerves, just like, level here, you know, because this is just stressful right now. It's kind of hard to hide yourself and take your medication (LA MSM).

In institutionalized settings such as prisons or drug treatment centres, individuals had diminished ability to maintain privacy around issues of medication, and many felt compelled to lie about or disguise their medication. Inadvertent disclosure of HIV status could result 
Table 1. Demographic and background variables of sample $(\mathrm{N}=152)^{a}$

\begin{tabular}{|c|c|c|c|}
\hline Variable & \%Women $(n=56)$ & $\% \operatorname{MSM}(n=52)$ & $\% \operatorname{IDU}(n=44)$ \\
\hline Years of age (mean, SD): & $39.4(8.7)$ & $40.0(6.5)$ & $42.8(6.8)$ \\
\hline Range (min $-\max )$ & $20-55$ & $28-56$ & $32-59$ \\
\hline \multicolumn{4}{|l|}{ Ethnicity $^{\mathrm{b}}$} \\
\hline White, non-Latino & 15.1 & 50.0 & 30.2 \\
\hline Latino & 20.8 & 16.6 & 44.2 \\
\hline African or Caribbean American & 60.4 & 31.0 & 23.3 \\
\hline Other & 3.7 & 2.4 & 2.3 \\
\hline \multicolumn{4}{|l|}{ Education $^{c}$} \\
\hline Never completed high school or GED & 40.4 & 8.8 & 19.0 \\
\hline High school or GED & 34.6 & 37.8 & 40.5 \\
\hline Some college & 23.1 & 22.2 & 33.3 \\
\hline College or post-college & 1.9 & 31.2 & 7.2 \\
\hline \multicolumn{4}{|l|}{ Primary income source } \\
\hline Own job & 16.4 & 22.9 & 0.0 \\
\hline Disability & 54.5 & 56.3 & 57.2 \\
\hline Public assistance, non-disability & 21.8 & 12.5 & 23.8 \\
\hline Family/friend/partner/spouse support & 3.6 & 0.0 & 0.0 \\
\hline Other & 3.7 & 8.3 & 19.0 \\
\hline \multicolumn{4}{|l|}{ Current marital status } \\
\hline Single & 39.2 & 82.4 & 53.5 \\
\hline Married or common-law & 30.4 & 4.0 & 16.3 \\
\hline Divorced, separated, or widowed & 30.4 & 13.6 & 30.2 \\
\hline \multicolumn{4}{|l|}{ Current relationship status } \\
\hline Not in a relationship & 16.1 & 60.0 & 52.3 \\
\hline In a relationship but not living together & 35.7 & 22.0 & 22.7 \\
\hline In a relationship and living together & 48.2 & 18.0 & 25.0 \\
\hline \multicolumn{4}{|l|}{ Substance use } \\
\hline Lifetime IDU & 47.2 & 26.0 & 100.0 \\
\hline \multicolumn{4}{|l|}{ HIV medication therapy } \\
\hline Current & 75.0 & 66.7 & 72.7 \\
\hline Past & 12.5 & 21.6 & 15.9 \\
\hline Never been on meds & 12.5 & 11.7 & 11.4 \\
\hline
\end{tabular}

${ }^{\mathrm{a}}$ Percentage of those with valid data; missing data did not exceed $8 \%$ for any variable unless specified; ${ }^{\mathrm{b}}$ missing data for MSM on ethnicity $=19.2 \%(n=10) ;{ }^{c}$ missing data for MSM on education $=13.5 \%(n=7)$.

from structural and organizational factors, such as being assigned to an HIV/AIDS ward or having to wait in queues for medication. One woman said about her detox:

I don't like standing in no line, with everybody looking at me taking that many pills a day. But I was in detox one day and a girl seen me get all these... 'Good Lord, why you taking so much medicine?' I didn't know what to say. I said, 'I don't know what all this shit is. Some vitamins.' I lied. Some people I don't tell (NY WOM).

Medications and treatment necessitate medical visits that can also 'out' one or be a source of shame:

Everything is very secretive. I can't talk about this with anybody. No one knows I have it, so therefore, my medications... if I'm going to the doctor's, I go by myself and nobody knows I'm there. Nobody knows I'm here. It took me several months to even come to this 


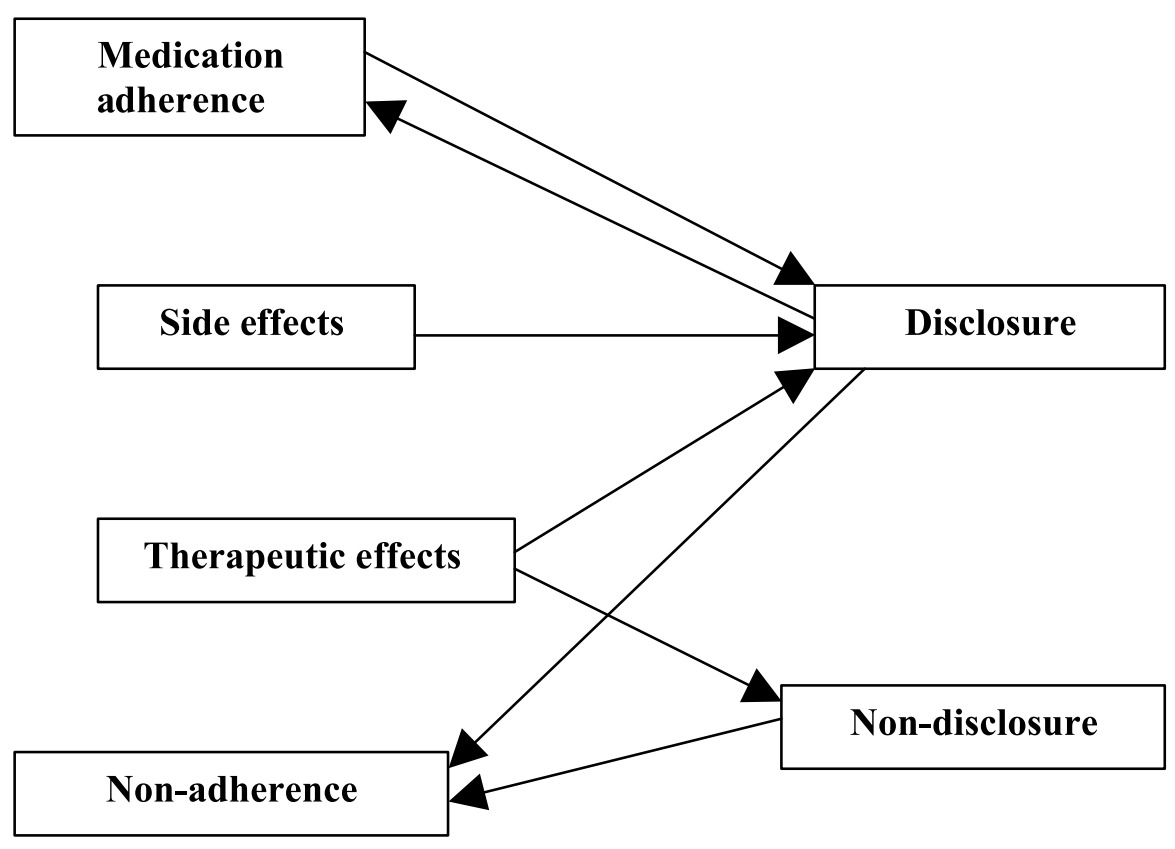

FIG. 1. Interrelationships between disclosure and HAART.

building. I couldn't do it. I would literally go around the back and sneak in or wait until no cars are coming. I wear dark shades. I come in the back way. I'm just devastated, scared. If somebody's dropping me up here, I'll have them drop me several blocks away because I don't want the association. It's just something I'm ashamed of. I can't help it but it's a reality (LA MSM).

\section{Side effects of HAART as precipitating disclosure}

Adverse side effects can also serve as non-verbal signs of illness and thus can 'out' individuals. Some are acutely aware of negative physical changes due to medications:

It has aged me terribly. I look at least ten years older than I normally would. The AZT greyed my hair, wrinkled my face, and that damage never. . .never went back. It just did it permanently. I find this particular mix is not harmful to my face or my body outside of the bloating which I went through for five years. I no longer bloat at all. I can get into clothes I had when I worked at the store, and I'm so delighted I got a wardrobe. But it makes a difference because. ..it's hard to feel good about oneself. I don't care what the facade is... it's very difficult to feel you look good and feel good (SF IDU-MSn).

Some avoided taking medications at work because of shorter-term side effects that others might observe: '[At work, medications] start to nauseate me and make me feel drawn and tired and sluggish' (LA MSM). 
Therapeutic effects of HAART as delaying or impeding disclosure

The desired therapeutic effects of HAART can delay or impede disclosure. Several expressed their desire to avoid the stigmatizing signs of advanced HIV disease and instead to appear healthy. This desired healthy appearance enabled individuals to 'pass' (Goffman, 1961) as healthy, creating additional disclosure options. For example, some delay disclosure, waiting until they are on medications and looking 'well':

I did not tell them until I was on the meds and [the meds] were working, because I didn't want them to worry, 'Oh, he's going to die. He's going to die.' I just wanted them to know that I'm part of the cure and not the problem' (LA IDU).

Conversely, as a result of HAART and looking healthy, some are able to deny that they are HIV infected:

They don't know. They started a rumour, but I don't look it. Do you know what an HIV guy looks like? He don't look like me. I'm built. I'm big. They're skinny. They can barely walk. I just convince them quick (LA IDU).

\section{Closetedness about medication as promoting non-adherence}

A perceived need not to disclose can foster non-adherence. As one IDU reported:

I have to remember to take them. At first I felt conscious about taking them out when it was time to take them. Or having them with me. Or people would ask me, 'what are you taking?' And I would miss dosages like that (NY IDU).

One gay man missed doses of medications because he was afraid medications would 'out' him to sexual partners to whom he had not disclosed his HIV status:

I am very careful about spending the night over at somebody's house. I'll be very careful of letting them see me take my medication because they might be curious about, 'What kind of medication you taking?' Then you have to [explain] it (MIL MSM).

\section{Disclosure impeding adherence}

As a result of openness about being HIV infected and on medications, some faced antagonistic reactions from others who hold negative beliefs or expectations of HAART (e.g. because of adverse side effects) that can then impede adherence:

Other patients that come over here, or I see, say, 'Oh, you shouldn't take those pills.' Or, 'Those pills are no good because they make your stomach look big,' and stuff like that (NY WOM).

Following disclosure, antagonism toward medications may also arise due to mistrust about the medical establishment in general:

I heard so many different diverse opinions about it from different people - 'Those things are gonna kill you, that shit don't work, they're using you as a guinea pig,' that together with the way that I was taking them too erratically, it worked on me (NY IDU). 
Such opposition can also arise after disclosure due to political views and distrust based on historical instances of discrimination and medical experimentation:

Initially, my ex wasn't crazy about it. He's African-American... and you know the first thing he thought was the Tuskegee experiments. He had it in his head that somebody deliberately gave me this because I'm Native American and have half-black children. $\mathrm{He}$ was way into all that conspiratorial evil stuff (LA WOM).

Some are able to counter such antagonism effectively-recognizing its basis in misinformation, or their own right to autonomous decision making. Yet responding effectively to such antagonism may not be easy:

Because of all the misinformation out there, a lot of people are ignorant about protease inhibitors, and I had to get that straight in my mind and with my health care provider. I'm pretty well informed about it now (NY IDU).

One woman said her boyfriend is 'anti-medication': 'That's his individual choice, but he doesn't tell me not to take it. I would tell him to go take a hike anyway’ (NY WOM).

\section{Disclosure facilitating adherence}

On the other hand, in the era of HAART, HIV disclosure can also lead to social support that can promote health and facilitate starting and adhering to treatment:

If I would have told them when I first found out, then maybe I could have got help back then, and my disease wouldn't have progressed as rapidly as it did. So I think it's more out of self-pity and demoralization that I didn't tell them earlier (LA IDU).

Many participants reported that individuals within their social network to whom they had disclosed reacted positively, and often asked if these participants were keeping up with their medication regimens - showing support, involvement and acceptance: 'Just my boyfriend knows.... He gets on me: makes sure I take it every day' (MIL WOM).

Indeed, infected individuals often appreciate this support:

They're always on my back to make sure I take my medications... my wife, my mother, my brother, people that care, that support me. They're always aware. At the time I'm supposed to take the medication, they'll call me. . I just like the support. I appreciate that very much (NY IDU).

Yet positive social support, although facilitating adherence, may also create certain burdens or pressures due to overly optimistic expectations concerning these treatments:

My mother thinks, 'oh, you're taking medication, you're going to live a long time.' But when the virus hits you, there's nothing you can do. She figured, 'oh you take the medication, you're going to be all right.' I explained to her what I know about it: that that's not so (NY WOM). 


\section{Discussion}

HIV disclosure and adherence to HAART can shape each other in several important ways. On the one hand, HAART can 'out' individuals, leading to efforts to disguise medications or alter treatment regimens, in turn potentially affecting adherence. The physiological effects of these medications - both good and bad — can also shape disclosure. Side effects can serve as a proxy for disclosure, and beneficial effects can make it easier to delay or avoid divulging one's status. Disclosure can also facilitate initiation and maintenance of treatment. Yet at times, the interplay between disclosure and adherence reveals a conflict of goals. The desire to stay healthy and fight HIV (by taking medications) may conflict with a desire to maintain privacy about one's HIV status (by not taking the medications around other people). Disclosure may also be a key variable in obtaining or mediating social support, which can be important in adherence.

These dynamics between disclosure and adherence have been under-studied and need to be further examined. Attention has generally been given, on the one hand, to interventions and approaches for assisting individuals with issues of disclosure; and on the other hand, toward enhancing medication adherence. The interconnections-both positive and negative-between these two sets of issues in the lives of PLWH need to be more fully appreciated and explored. At the same time, the potential impact of disclosure on adherence calls for renewed and revised attention to issues of disclosure in HIV prevention efforts and research. The disclosure literature has focused little, if at all, on issues of adherence. Further research on disclosure should examine the ways in which these decisions interact with adherence patterns - how fears of disclosure may impede or enhance adherence, and how HAART may delay disclosure in ways that can in turn facilitate the practice of unsafe sex that further transmits the virus. Such delays in disclosure may also lead to an individual receiving less support than he or she otherwise might, in ways that may diminish adherence. Thus, a better understanding of the dynamics between desires to adhere to medications on the one hand, and to maintain privacy on the other, can inform the development of interventions that allow for rational non-disclosure that does not result in decreased adherence. Despite treatment regimens becoming easier than in the past (e.g. with fewer pills) and stress related to the need to take pills in public decreasing to some extent, these issues remain a significant problem for many PLWH.

In conclusion, future studies in each of these two domains - disclosure and adherencewould benefit from greater recognition of the significance of these complex interactions. In this way, researchers, clinicians and others can advance appropriately nuanced understanding and sensitivity regarding these issues, improve the health and quality of life of infected individuals and stymie the continued spread of the epidemic.

\section{Acknowledgements}

This research was funded by National Institute of Mental Health grants U10-MH57636, U10-MH57631, U10-MH57616 and U10-MH57615; NIMH centre grants P30-MH058107 (Mary Jane Rotheram-Borus, PhD, PI), P30-MH57226 (Jeffrey A. Kelly, PhD, PI), P30MH43520 (Anke A. Ehrhardt, PhD, PI) and P30-MH062246 (Thomas J. Coates, PhD, PI).

The authors thank the men and women who participated in these interviews: Ellen Stover, PhD, Willo Pequegnat, PhD, Christopher M. Gordon, PhD, and Dianne Rausch, $\mathrm{PhD}$, at NIMH for their support of this research; and Susan Tross, PhD, and Gary Dowsett, $\mathrm{PhD}$, for methodological guidance, and Daniel Fishman and Jennifer Hersh, for editorial assistance. 
This project was conducted by the NIMH Healthy Living Trial Group, including site PIs and NIMH staff collaborators: Mary Jane Rotheram-Borus, PhD (UCLA), Jeffrey A. Kelly, $\mathrm{PhD}$ (MCW), Anke A. Ehrhardt, PhD (NYSPI/Columbia University), Margaret A. Chesney, $\mathrm{PhD}$ (UCSF), and Willo Pequegnat, $\mathrm{PhD}(\mathrm{NIMH})$; Co-PIs, Investigators, Collaborating Scientists: Naihua Duan, PhD, Martha Lee, PhD, Marguerita Lightfoot, PhD, Rise B. Goldstein, $\mathrm{PhD}, \mathrm{MPH}$, Fen Rhodes, PhD, Robert Weiss, PhD, Lennie Wong, PhD, Tyson Rogers, M.A., Philip Batterham, M.A. (UCLA), Lance S. Weinhardt, PhD, Eric G. Benotsch, PhD, Michael J. Brondino, PhD, Sheryl L. Catz, PhD, Cheryl Gore-Felton, $\mathrm{PhD}$, Steven D. Pinkerton, PhD (MCW), Robert H. Remien, PhD, A. Elizabeth Hirky, PhD, Robert M. Kertzner, M.D., Sheri B. Kirshenbaum, PhD, Lauren E. Kittel, Psy.D., Robert Klitzman, M.D., Bruce Levin, PhD, Susan Tross, PhD (NYSPI/Columbia University), Stephen F. Morin, PhD, Mallory O. Johnson, PhD (UCSF), Don C. Des Jarlais, PhD (Beth Israel Medical Center, New York City), Hannah Wolfe, PhD (St. Luke's Roosevelt Medical Center, New York City); Site Project Coordinators: Daniel Hong, MA (UCLA), Kristin Hackl, MSW, Margaret Peterson, MSW (MCW), Joanne Mickalian, MA (UCSF); and NIMH: Ellen Stover, PhD, Christopher M. Gordon, PhD, Dianne Rausch, PhD.

\section{References}

Ammassari, A., Murri, R., Pezzotti, P., Trotta, M.P., Ravasio, L., De Longis, P., lo Caputo, S., Narciso, P., Pauluzzi, S., Carosi, G., Nappa, S., Piano, P., Izzo, C.M., Lichtner, M., Rezza, G., Monforte, A., Ippolito, G., D’Arminio Moroni, M., Wu A.W., Antinori, A. \& Adicona Study Group (2001). Selfreported symptoms and medication side effects influence adherence to highly active antiretroviral therapy in persons with HIV infection. Fournal of Acquired Immune Deficiency Syndromes, 28, 445-449.

BABCOCK, J.H. (1998). Involving family and significant others in acute care. In: Aronstein, D. M. \& ThOMPson, B. J. (Eds), HIV and social work (pp. 101-108). Binghamton: Harrington.

Chesney, M.A. \& SMith, A.W. (1999). Critical delays in HIV testing and care: the potential role of stigma. American Behavioral Scientist, 42 (7), $1162-1174$.

Chesney, M.A., Ickovics, J.R., Chambers, D.B., Gifford, A.L., Neidig, J., Zwickl, B. \& Wu, A.W. (2000). Self reported adherence to antiretroviral medications among participants in HIV clinical trials: the AACTG adherence instruments. Patient Care Committee \& Adherence Working Group of the Outcomes Committee of the Adult AIDS Clinical Trials Group (AACTG). AIDS Care, 12 (3), 255-266.

Crespo-Fierro, M. (1997). Compliance/adherence and care management in HIV disease. Fournal of the Association of Nurses in AIDS Care, 8 (4), 43-54.

DeMatteo, D., Wells, L.M., Goldie, R.S. \& King, S.M. (2002). The family context of HiV: a need for comprehensive health and social policies. AIDS Care, 14 (2), 261-278.

Derlega, V., Metts, S., Petronio, S. \& Margulis, S. (1993). Self-disclosure. Newbury Park, CA: Sage Publications.

Duran, S., Savès, M., Spire, B., Cailleton, V., Sobel, A., Carrieri, P., Salmon, D., Moatti, J.P., Leport, C. \& The Aproco Study Group (2001). Failure to maintain long-term adherence to highly active antiretroviral therapy: the role of lipodystrophy. AIDS, 15 (8), 2441-2444.

Garcia De Olalla, P., Knobel, H., Carmona, A., Guelar, A., Lopez-Colomes, J.L. \& Cayla, J.A. (2002). Impact of adherence and highly active antiretroviral therapy on survival in HIV-infected patients. Fournal of Acquired Immune Deficiency Syndrome, 30 (1), 105-110.

Gielen, A.C., Fogarty, L., O'Campo, P., Anderson, J., Keller, J. \& Faden, R. (2000a). Women living with HIV: disclosure, violence and social support. Fournal of Urban Health, 77 (3), 480-491.

Gielen, A.C., McDonnell, Burke, J.G. \& O'CAMpo, P. (2000b). Women's lives after an HIV-positive diagnosis: disclosure and violence. Maternal and Child Health, 4 (2), 111-120.

Gifford, A., Bormann, J., Shively, M., Wright, B., Richman, D. \& Bozzette, S. (2000). Predictors of selfreported adherence and plasma HIV concentrations in patients on multidrug antiretroviral regimens. fournal of Acquired Immune Deficiency Syndromes, 23 (5), 386-395.

Goffman, E. (1961). Asylums: essays on the social situation of mental patients and other inmates. London: Penguin.

Johnson, M.O., Charlebois, E., Morin, S.F., Catz, S.L., Goldstein, R.B., Remien, R.H., Rotheram-Borus, M.J., Kitell, L., Samimy-Muzaffar, F., Lightfoot, M., Gore-Felton, C., Chesney, M.A. \& The Nimh 
Healthy Living Project Team. (in press). Perceived adverse effects of antiretroviral therapy. Fournal of Pain and Symptom Management.

Johnson, M.O., Catz, S.L., Remien, R.H., Rotheram-Borus, M.J., Morin, S.F., Charlebois, E., GoreFelton, C., Goldstein, R.B., Wolfe, H., Lightfoot, M., Chesney, M.A. \& The Nimh Hlp Team (2003a). Theory guided, empirically supported avenues for intervention on HIV medication nonadherence: findings from the Healthy Living Project. AIDS Patient Care and STD, 17, 645-656.

Johnson, M., Stallworth, T. \& NeIlands, T. (2003b). The drugs or the disease? Causal attributions of symptoms held by HIV positive adults on HAART. AIDS and Behavior, 7 (2), 109-117.

Kalichman, S.C. (1995). Understanding AIDS: a guide for mental health professionals. Washington, DC: American Psychological Association.

Kalichman, S.C. \& Nachimson, D. (1999). Self-efficacy and disclosure of HIV-positive serostatus to sex partners. Health Psychology, 18, 281-287.

Kastrissios, H., Su' Arez, J.R., Hammer, S., Katzenstein, D. \& Blaschke, T.F. (1998). The extent of nonadherence in a large AIDS clinical trial using plasma dideoxynucleoside concentrations as a marker. AIDS, 12, 2305-2311.

Kirshenbaum, S.B. (1999). Maternal disclosure of HIV/AIDS in relation to children's adjustment. Doctoral dissertation, St. John's University, UMI \#9952389.

Kirshenbaum, S.B. \& Nevid, J.S. (2002). The specificity of maternal disclosure of HIV/AIDS in relation to children's adjustment. AIDS Education and Prevention, 14 (1), 1-16.

KLITZMAN, R. (1999). Self-disclosure of HIV serostatus to sexual partners: a qualitative study of issues faced by gay men. Fournal of the Gay and Lesbian Medical Association, 3 (2), 39-49.

Klitzman, R. \& Bayer, R. (2003). Mortal secrets: truth and lies in the age of AIDS. Baltimore: Johns Hopkins University Press.

Mansergh, G., Marks, G. \& Simoni, J. (1995). Self-disclosure of HIV infection among men who vary in time since seropositive diagnosis and symptomatic status. AIDS, 9, 639-644.

Marks, G. \& Crepaz, N. (2001). HIV-positive men's sexual practices in the context of self-disclosure of HIV status. fournal of Acquired Immune Deficiency Syndromes, 27 (1), 79-85.

Marks, G., Richardson, J. \& Maldonado, N. (1991). Self-disclosure of HIV infection to sexual partners. American fournal of Public Health, 81 (10), 1321-1322.

Marks, G., Ruiz, M., Richardson, J., Reed, D., Mason, H., Sotelo, M. \& Turner, P. (1994). Anal intercourse and disclosure of HIV infection among seropositive gay and bisexual men. Fournal of Acquired Immune Deficiency Syndromes, 7 (8), 866-869.

Mellins, C., Havens, J., Mccaskill, E., Leu, C., Brudnew, K. \& Chesney, M. (2002). Mental health, substance use and disclosure are significantly associated with the medical treatment adherence of HIV-infected mothers. Psychology, Health and Medicine, 7 (4), 451-460.

Molaghan, J.B. (1997). Adherence issues in HIV therapeutics. Introduction: the situation. Fournal of the Association of Nurses in AIDS Care, 8, 7-9.

Oette, M., Juretzko, P., Kroidl, A., SAgir, A., Wettstein, M., Siegrist, J. \& Häussinger, D. (2002). Lipodystrophy syndrome and self-assessment of well-being and physical appearance in HIV-positive patients. AIDS Patient Care and STDs, 16 (9), 413-417.

Paterson, D.L., Swindells, S., Mohr, J., Brester, M., Vergis, E.N., Squier, C., Wagener, M.M. \& Singh, N (2000). Adherence to protease inhibitor therapy and outcomes in patients with HIV infection. Annals of Internal Medicine, 133, 21-30.

Patton, M.Q. (1990). Humanistic psychology and humanistic research. Special issue: human inquiry \& the personcentered approach. Person-Centered Review, 5, 191-202.

Perry, S., Card, C., Moffatt, M., Jr., T., Fishman, B. \& Jacobsberg, L. (1994). Self disclosure of HiV infection to sexual partners after repeated counseling. AIDS Education and Prevention, 6, 403-411.

Perry, S., Ryan, J., Fogel, K., Fishman, B. \& Jacobsberg, L. (1990). Voluntarily informing others of positive HiV test results: patterns of notification by infected gay men. Hospital and Community Psychiatry, 41 (5), 549-551.

REMIEN, R.H. (1998). Adhering to HIV combination therapy: the role of the pharmacist. Pharmacy Times, 5 (98), 28 37.

Remien, R.H., Hirky, A.E., Johnson, M., Weinhardt, L., Whittier, D. \& Le Giang, M. (2003). Adherence to medication treatment: a qualitative study of facilitators and barriers among a diverse sample of HIV-positive men and women in four US cities. AIDS \& Behavior, 7 (1), 61-72.

Rodriguez Rosado, R., Jimenez Nacher, I. \& Soriano, V. (1998). Virological failure and adherence to antiretroviral therapy in HIV-infected patients. AIDS, 12, 1112-1113.

Sepkowitz, K.A. (2001). AIDS - the first twenty years. New England fournal of Medicine, 344 (23), 1764-1772. Serovich, J.M. (2001). A test of two HIV disclosure theories. AIDS Education and Prevention, 13 (4), $355-364$. 
Simoni, J.M., Mason, H.R., Marks, G., Ruiz, M.S., Reed, D. \& Richardson, J.L. (1995). Women's self-disclosure of HIV infection: rates, reasons, and reactions. fournal of Consulting and Clinical Psychology, 63 (3), 474-478.

Stein, M.D., Freedberg, K.A., Sullivan, L.M., Savetsky, J., Levenson, S.M., Hingson, R. \& Samet, J.H. (1998). Sexual ethics: disclosure of HIV-positive status to partners. Archives of Internal Medicine, 158 (3), $253-257$.

Stempel, R., Moulton, J. \& Moss, A. (1995). Self-disclosure of HIV-1 antibody test results: the San Francisco general hospital cohort. AIDS Education and Prevention, 7 (2), 116-123.

STrauss, A. \& Corbin, J. (1990). Basics of qualitative research - techniques and procedures for developing grounded theory. Newbury Park, CA: Sage.

WAHL, L. \& Nowak, M. (2000). Adherence and resistance: predictions for therapy outcome. Proceedings of the Royal Society. Biological, 267, 835-843. 
Copyright of AIDS Care is the property of Carfax Publishing Company and its content may not be copied or emailed to multiple sites or posted to a listserv without the copyright holder's express written permission. However, users may print, download, or email articles for individual use. 
Copyright of AIDS Care is the property of Carfax Publishing Company and its content may not be copied or emailed to multiple sites or posted to a listserv without the copyright holder's express written permission. However, users may print, download, or email articles for individual use. 